\title{
THE INFLUENCE OF SERVICE QUALITY, RELIGIOUS COMMITMENT AND TRUST ON THE CUSTOMERS' SATISFACTION AND LOYALTY AND DECISION TO DO THE TRANSACTION IN MANDIRI SHARIA BANK OF JAWATIMUR
}

\author{
Rachmad Hidayat and Sabarudin Akhmad \\ Trunojoyo University, Madura \\ (rachmad_h@ymail.com)
}

\begin{abstract}
This study tested the causal relationship of service quality, religious commitment and trust on customers' satisfaction, loyalty and decision to repeat their transaction in sharia banking services. This research used quantitative approach to describe the causal relationship between the variables through hypothesis testing. The samples in this research are 160 respondents. Structural equation modeling (SEM) is used to analyze this research. This research findings shows that the quality of service and customers' trust, satisfaction and loyalty simultaneously influenced the decision to repeat their transaction in that banking service. The customers' satisfaction and loyalty are intervening variables that linked the service quality and the customers' trust with the decision to repeat their banking transaction. The religious commitment had insignificant influence toward the service quality; however, it had significant influence toward the loyalty and decision to repeat their banking transaction.
\end{abstract}

Penelitian ini menguji hubungan kausalitas kualitas layanan, kepercayaan dan komitmen beragama nasabah terhadap kepuasan, loyalitas dan keputusan bertransaksi ulang layanan perbankan syariah. Penelitian ini menggunakan pendekatan kuantitatif yang bermaksud memberikan penjelasan hubungan kausalitas antar variabel melalui pengujian hipotesis. Jumlah sampel penelitian sejumlah 160 responden. Analisis yang digunakan adalah model persamaan struktural (Structural Equation Modeling atau SEM). Hasil penelitian menunjukkan bahwa kualitas layanan dan kepercayaan nasabah, kepuasan dan loyalitas secara bersama-sama berpengaruh terhadap keputusan bertransaksi ulang layanan perbankan. Kepuasan dan loyalitas nasabah menjadi variabel intervening yang menghubungkan kualitas layanan dan kepercayaan nasabah dengan keputusan bertransaksi ulang layanan perbankan. Komitmen beragama berpengaruh tidak signifikan terhadap kualitas layanan, namun berpengaruh signfikan terhadap loyalitas dan keputusan bertransaksi ulang layanan perbankan

Keywords: satisfaction, loyalty, religious commitment, satisfaction, loyalty and decision to repeat banking transaction 


\section{A. Introduction}

Mandiri Sharia bank has the service motto of (1) Ikhlas: to the problem with the pure intention just because of Allah Swt, to consider the effectiveness of service as the act of worshipping Allah, to try to as much as possible to conduct the services just to gain Allah's favor, to always think clearly and speak the truth when servicing or when receiving complaint, to have good attitude and to behave as good role model for work colleagues. (2) Quick: according to the standard of the time promised, quick respond toward the customers' needs, skilled in providing good services. (3) accurate: accurate and discipline in work, execute all the jobs correctly until the jobs are all completed, and not postponing the jobs. Three elements of services of Mandiri Sharia Bank of Salatiga are (1) The Physic that is the office complex/the building (2)The people that is the human resources of the bank, (3) the process that is the processing stage of the services ${ }^{1}$.

The progress of the sharia banks in reformation era was marked by the enactment of Law No. 10 of 1998 that explains in detail the legal basis and the kinds of services that can be operated and implemented by the sharia banks. This government policy has also played a role in the progress of the sharia banking services. Consequently, the level of competition has also increased. Based on the annual report of the Central Bank of Indonesia (The Bank of Indonesia) in 2013, quantitatively there have had been a raise in the number of sharia banks and sharia credits services, in which, in 1998, there was only one public sharia bank and seventy six sharia credit services, in 2013 the number of sharia banks has increased to 31 units of sharia banks which consists of 6 public sharia banks and 25 units of sharia services, and the number of sharia credits services has also mounted to 139 units. The progressive increase of sharia banks can be a sustainable competitive advantage toward the on-going tight competition in banking industry. In this competitive industry, the banks are obligated to implement high quality services in all their products and services. The products and services offered by the banks are intended to fulfill the needs of the customers. The bank has to be creatively invent product and services that can answer the needs of its customers.

The success of the bank to influence to customers in making decisions regarding to the financial transaction is strongly influenced by the efforts to gain the customers' trust. The customers' trust toward the bank is one of the priceless assets for the bank. This due to trust that is considered as the basis of the relationship with the customer. Bank with good reputation generally would be more appealing for the customers' candidate; because they are assured that the bank is of good quality and can be trusted. The trusted bank is a guarantee for a consistent performance of a product and provided for every need of the

${ }^{1}$ Surat Edaran Direksi No. 10/001/UMM tanggal 30 Januari 2008 tantang Visi, Misi dan BSM Shared Values "ETHIC". 
customers. The decision to repeat the transaction actually is influenced by the customers' attitude toward the product or the service ${ }^{2}$. The attitude is a thorough evaluation that enables someone to respond in favorable ways or not toward the evaluated object ${ }^{3}$. The transaction behaviour is one among many that could be influenced by the quality of service ${ }^{4}$.

This research is based on the literature review and the empirical study on the marketing of banking services. This research is generated from the influence of the service's quality toward the customers' satisfaction and the customers' loyalty. The measurement of service's quality is based on the expectation and perception of the customer and the gap between those two. A service process can be said of quality if the bank could fulfill the five dimension of service quality. These dimensions are (1) tangible dimension, in which the bank has to be able to provide physical facility such as office building, office supplies and furniture, transaction tools and machines, and employees' appearance that met the customers' expectation. (2) Reliability dimension in which the bank has to have the ability to provide services as promised accurately and reliably. (3) emphatic dimension, in which the bank are emphatic such as caring to the needs and wants of the customers. (4) responsiveness dimension, in which the bank is able to provide quick respond and responsive to the complaint or problem faced by the customer. (5) assurance dimension in which the bank can provide guaranty toward the service quality provided for its customers.

The customers would measure their level of satisfaction based on their perception and expectation toward the banking services that they received. If the perception is beyond or equal with the expectation then the customer would be satisfied toward the services provided by the bank. The customers' satisfaction is measured using three indicators namely, (1) Overall satisfaction, where the customers will evaluate their current consumption experience that based on the practices, obstacles, and standardization of banking services, (2) confirmation of expectation in which the customer compared the suitability between the level of satisfaction that she/he felt and her/his expectation, (3) comparison of ideal in

${ }^{2}$ Taylor, S. A., \& Hunter, G., An exploratory investigation into the antecedents of satisfaction, brand attitude, and loyalty within the (B2B) eCRM industry. Journal of Consumer Satisfaction Dissatisfaction and Complaining Behavior, Vol. 16. 2003, 19.

${ }^{3}$ Louro, M. J., Pieters, R., \& Zeelenberg, M. Negative Returns on Positive Emotions: The Influence of Pride and Self-Regulatory Goals on Repurchase Decisions. Journal of Consumer Research, Vol. 31 No. 4. 2005, 833.

4 Preis, M. W., The impact of interpersonal satisfaction on repurchase decisions. Journal of supply chain management, Vol. 39 No. 2. 2003, 30. 
which the customer compared the service performance with the ideal condition perceived by the customer ${ }^{5}$.

The customers' satisfaction would influence the loyalty of the customer to the bank. The loyalty consists of two components, which are, the loyalty as the customers' behavior in carrying the banking transaction and the loyalty as the attitude of the customer toward the bank ${ }^{6}$. The loyalty is manifested trough (1) trust of the customer to the bank, (2) emotion commitment, that is the psychological commitment of the customer toward the bank, (3) switching cost that is the customer no not remove his/her transaction to other banks, (4) word of mouth which is a publicity behavior that conducted by the customer toward the bank, and (5) cooperation is the customers' behavior that shows their cooperation with the bank. The more satisfied the customer with the bank, the more loyal she/he and she/he will behave as loyal customer that characterized by their repeated transactions, informing their experience to others, not removing their savings or investment to other banks, and fully trust the concerned bank.

In sharia banking industry, the products and services offered are almost similar with the Al-wadiáh (saving), financing with the shared-outcome, Baiál Murabahah, Bai' as-Salam, Bai' al Istishna', Al-Ijarah (Leasing), Al-Wakalah (Trusteeship), and Al-Kafalah (Guaranti). Through these, the customers could compare the services and products offered by the bank, which is better for them. The bank with better quality of services and satisfactory to the values needed by its customers would be chosen as the prominent bank. The centre of attention in organizational system of the big banks is communication or feedback mechanism from the customers on how was the quality of the service provided, in order to find out whether or not the bank has been able to fulfill the needs and expectations of the customers. Theoretically, there is an empirical justification of the assumption on the strong existence and causal relationship between the service quality, customers' trust and religious commitment toward the decision to repeat the banking transaction. Another justification that can be made is the existence of relationship between service quality, customers' trust and religious commitment toward the decision to repeat the banking transaction, either directly or through the customers' satisfaction and loyalty. In addition to that, the service marketing theories have given a hand on justification that has been put forward. Therefore, a test needed to be conducted to empirically measure the validity of this theory.

${ }^{5}$ Fomell C, MD Johnson, EW. Anderson, Jaesung Cha and B. Everin Bryant. The American Customer Satisfaction Index: Nature, Purpose and Findings. Journal of Marketing. Vol. 60 No. 10. 1996, 7.

${ }^{6}$ Baloglu, S. Dimensions of customer loyalty: Separating friends from well wishers. The Cornell Hotel and Restaurant Administration Quarterly, Vol. 43 No. 1. 2002, 47. 
The Influence of Service Quality, Religious Commitment and Trust on The Customers' Satisfaction and Loyalty and Decision to Do The Transaction in Mandiri Sharia Bank of Jawatimur

This research is designed to find out the relationship between the research variables (service quality, customers' trust and religious commitment toward the customers' satisfaction and loyalty and the decision to repeat the sharia banking transaction. This research is an explanatory research to find out and explain the causal relationship between tested hypotheses ${ }^{7}$. This research used the quantitative approach to give causality explanation between the tested variables trough hypothesis testing. The number of respondents in this research is 160 respondents. This number sample was chosen based on: first, the guideline of sample size of 100-200 samples; Second, the number of indicators used in overall latent variables, times with $5-10^{8}$. In this research, there were 21 indicators of the research, therefore, the number of samples were ranging from 105 to 210 respondents. the respondents were allocated in 10 main branches of Mandiri Sharia Bank of Jawa Timur. The respondents allocation for each branch was equally allocated, 20 respondents for each branch. The samples were chosen using the systematic random sampling method. In this technique, each respondents has one equal chance to be chosen as research sample. The hypotheses being put forward in this research were:

Hypothesis 1: the quality of service significantly influenced the customers' satisfaction in Mandiri Sharia Bank

Hypothesis 2: trust significantly influenced the customers' satisfaction toward the Mandiri Sharia Bank

Hypothesis 3: Customers' religious commitment significantly influenced the Mandiri Sharia Bank customer' satisfaction

Hypothesis 4: The quality of service significantly influenced the customers' satisfaction of the Mandiri Sharia Bank

Hypothesis 5: Trust significantly influenced the loyalty of the Mandiri Sharia Bank customer

Hypothesis 6: Religious commitment significantly influenced the loyalty of the Mandiri Sharia Bank customer

Hypothesis 7: customers' satisfaction significantly influenced the loyalty of the customer in Mandiri Sharia Bank

Hypothesis 8: Service quality significantly influenced the customers' decision to repeat the banking transaction in Mandiri Sharia Bank

Hypothesis 9: Trust significantly influenced the customers 'decision to repeat the banking transaction in Mandiri Sharia Bank

7 Nazir, Mohammad. 1988. Metode Penelitian. (Cet 3; Jakarta: Ghalia Indonesia, 1988), p.99.

${ }^{8}$ Ferdinand, Augusty. Struktural Equation Modeling (SEM) Dalam Penelitian Manajemen. (Semarang: Universitas Diponegoro, 2000), p. 44. 
Hypothesis 10: Religious commitment significantly influenced the customers' decision to repeat the banking transaction in Mandiri Sharia Bank Hypothesis 11: Customers' satisfaction significantly influenced the customers " decision to repeat the banking transaction in Mandiri Sharia Bank Hypothesis 12: Customers' loyalty significantly influenced the customers' decision to repeat the banking transaction in Mandiri Sharia Bank

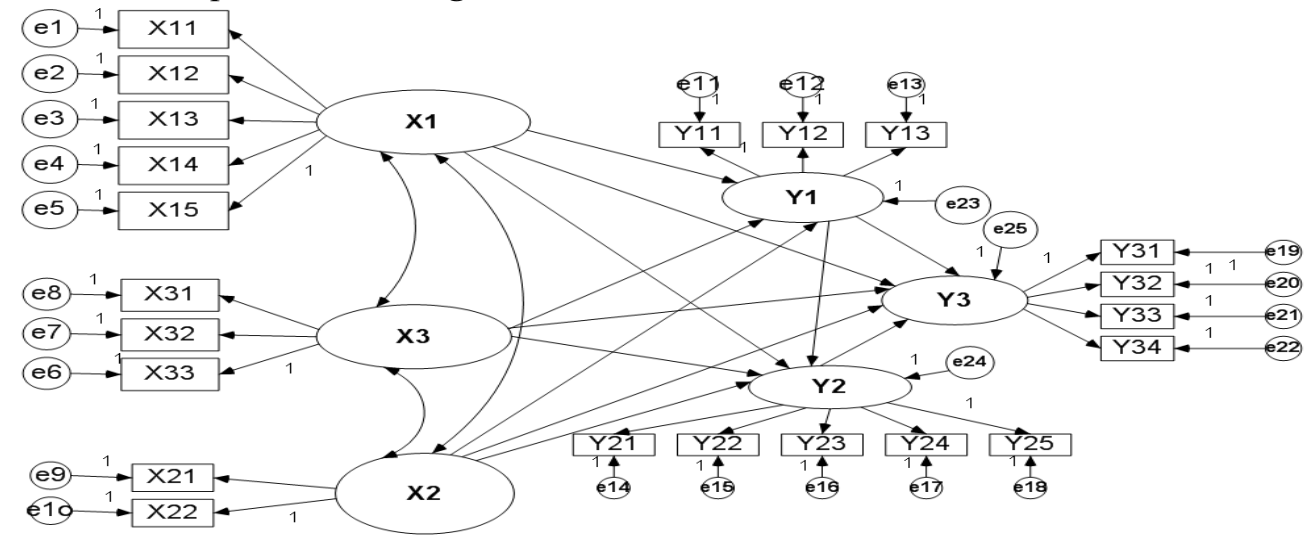

Gambar 1. Model Awal SEM Tahap awal

$\mathrm{X}_{1}$ : Service Quality

$\mathrm{X}_{1.1}$ : Tangibles

$\mathrm{Y}_{1}:$ Customers' Satisfaction

$\mathrm{X}_{1.2}:$ Reliability

$\mathrm{Y}_{1.1}:$ Overall satisfaction

$\mathrm{X}_{1.3}:$ Responsiveness

$\mathrm{Y}_{1.2}$ : Confirmation of expectation

$\mathrm{X}_{1.4}:$ Assurance

$\mathrm{Y}_{1.3}$ : Comparison of ideal

$\mathrm{X}_{1.5}$ : Empathy

$\mathrm{Y}_{2}$. : Customers' loyalty

$\mathrm{X}_{2}$ : Customers' Trust

$\mathrm{Y}_{2.1}:$ Trust

$\mathrm{X}_{2.1}$ : Past experience

$\mathrm{Y}_{2.2}$ : Emotion banking

$\mathrm{X}_{2.1}$ : Information and enthusiasm

$\mathrm{Y}_{2.3}$ : Switching cost

$\mathrm{X}_{3}$ : Religious commitment

$\mathrm{Y}_{2.4}$ : Word of Mouth

$\mathrm{Y}_{2.5}$ : Cooperation

$\mathrm{X}_{3.1}$ : Visit to worshipping places

$\mathrm{Y}_{3}$ : Decision to repeat the

$\mathrm{X}_{3.2}$ : Participation in religious banking transaction

activity

$\mathrm{Y}_{3.1}$ : cognitive

$\mathrm{X}_{3.3}$ : personal level of trust in $\mathrm{Y}_{3.2}$ : affective religion

$\mathrm{Y}_{3.3}:$ cog native

$\mathrm{Y}_{3.4}:$ Rebuy

B. Analysis and Discussion

The analysis of final stage SEM in specific is presented in the following Figure 2. 
The Influence of Service Quality, Religious Commitment and Trust on The Customers' Satisfaction and Loyalty and Decision to Do The Transaction in Mandiri Sharia Bank of Jawatimur

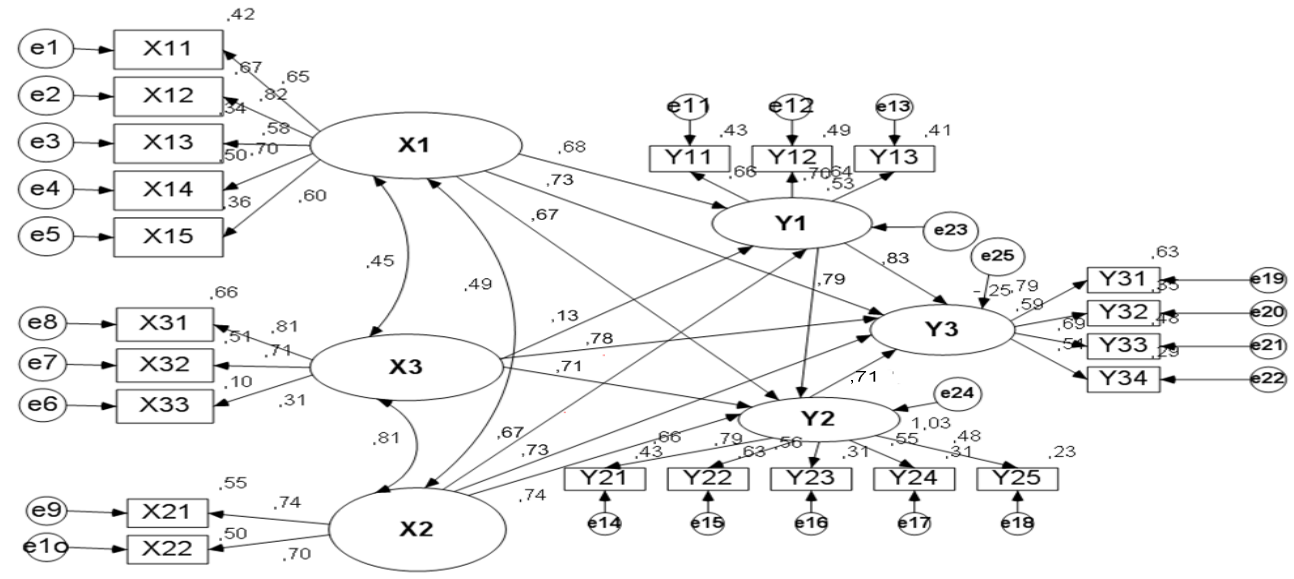

Figure 2 Final Stage of SEM Model

The hypothesis testing of this research were tested partially for each path of the analysis result using the structural equation modeling (SEM), the testing of the indirect influence is the additional outcome of the direct influence. The hypothesis testing of the direct influence was conducted by referring to the value of loaded factor $>0.05$, which means the influence is significant ${ }^{9}$. The result of this research hypotheses tests is shown in Table 1 which have direct relation.

Table 1. Path Coefficient Diagram of Direct Influence

\begin{tabular}{llll}
\hline $\begin{array}{l}\text { Independent } \\
\text { Variables }\end{array}$ & Dependent Variables & $\begin{array}{c}\text { Loading } \\
\text { Factor }\end{array}$ & Notes \\
\hline Service Quality & Customers' Satisfaction & 0,68 & Significant \\
\hline Customers' Trust & Customers' Satisfaction & 0,67 & Significant \\
\hline $\begin{array}{l}\text { Religious } \\
\text { Commitment }\end{array}$ & Customers' Satisfaction & 0,13 & Not Significant \\
\hline Service Quality & Customers' Loyalty & 0,67 & Significant \\
\hline Customers' Trust & Customers' Loyalty & 0,74 & Significant \\
\hline $\begin{array}{l}\text { Religious } \\
\text { Commitment }\end{array}$ & Customers' Loyalty & 0,71 & Significant \\
\hline $\begin{array}{l}\text { Customers' } \\
\text { Satisfaction }\end{array}$ & Customers' Loyalty & 0,79 & Significant \\
\hline Service Quality & $\begin{array}{l}\text { Decision to repeat the banking } \\
\text { transaction }\end{array}$ & Significant \\
\hline Customers' Trust & Decision to repeat the bankin£ 0,73 & Significant \\
\hline
\end{tabular}

${ }^{9}$ Ferdinand, Augusty. Struktural Equation Modeling (SEM) Dalam Penelitian Manajemen. (Semarang: Universitas Diponegoro, 2000), p. 44 


\begin{tabular}{lll}
\hline & transaction & \\
\hline $\begin{array}{l}\text { Religious } \\
\text { Commitment }\end{array}$ & $\begin{array}{l}\text { Decision to repeat the banking } 0,78 \\
\text { transaction }\end{array}$ & Significant \\
\hline $\begin{array}{l}\text { Customers' } \\
\text { Satisfaction }\end{array}$ & $\begin{array}{l}\text { Decision to repeat the banking } 0,83 \\
\text { transaction }\end{array}$ & Significant \\
\hline Customers' & $\begin{array}{l}\text { Decision to repeat the banking } 0,71 \\
\text { Loyalty }\end{array}$ & Significant \\
\hline
\end{tabular}

The service quality is significantly influenced the customers' satisfaction in Mandiri Sharia Bank. It means that the better the quality of service provided by the Mandiri Sharia Bank, the more satisfied the customer would be about that that specific service. The correlation between the service quality and the customer satisfaction is unseparated from the issues of banking services' creativity. To reach a qualified service in order to make the customers' satisfied, the bank has to be able to identify who are their customers and to understand the customers' level of perception and expectation of the quality of the services. The customers' satisfaction is the comparison between the perception and expectation of the customer toward the banking services experienced by that particular customer. The characteristics of the Mandiri sharia bank's customers concluded that the customers are those with the knowledge background and are able to compare the quality of good services and that the bank are able to satisfy its customers.

The outcome of this study support and enhanced the researchers conducted in the past. The quality of service as level of satisfaction rose from one particular transaction between the bank and the customers which is a psychological condition resulted when the emotional factor pushes expectation and adjusts with the past consumption experience ${ }^{10}$. This also means that there are differences when the quality of service is viewed as an attitude, because attitude and satisfaction are two different matter. The attitude of the customers are more relative toward the product of the services of the banking, meanwhile, satisfaction is an emotional reaction toward the previous experience. Quality of service can also be differentiated with the level of satisfaction; due to the perception on the quality of service is a thorough consideration or attitude in responding to the feature of a particular product or service. Level of satisfaction is related to a particular transaction in a relatively short period of time.

The quality of service is an assessment or global attitude related to superiority of a service, meanwhile, customers' satisfaction is a respond toward that particular assessment ${ }^{11}$. Customers' satisfaction assist the customer in

${ }^{10}$ Oliver R. L. Measurement and Evaluation of Satisfaction Process in Retail Setting. Journal of Retailing. Vol. 1981, 25.

${ }^{11}$ Parasuraman, V., A. Zeithaml and L. L. Beny.. A Conceptual Model of Service Quality and its Implication for Future Research. Journal of Marketing Research. Vol. 49. 1985, 41. 
The Influence of Service Quality, Religious Commitment and Trust on The Customers' Satisfaction and Loyalty and Decision to Do The Transaction in Mandiri Sharia Bank of Jawatimur

correcting or revising his/her perception toward the quality of service. The quality of service is a manifestation of a customers' thorough assessment attitude for a longer period of time ${ }^{12}$. The objective is to fulfill the customers' needs and expectation and the accuracy of conveying this objective in order to balance it with the customers' expectation (customers' satisfaction). This objective is aiming at achieving the ideal expectation, where the services provided by the bank is the optimum level of performance of the best performance as expected by the customers.

The customers will assess the quality of banking services based on their experience during the interaction with the bank. These experiences will influence their perception. Positive experience will enhance the customers' perception of the service quality which in turn will influence their level of satisfaction and so is the negative experience will trigger the dissatisfaction of the customers toward the services provided by the bank. This opinion supports Zeithaml and Bitner ${ }^{13}$ study which states that the more exclusive satisfaction is influenced by the service quality.

Service quality is the result of evaluation and present experience and is expected to have direct and positive influence toward the overall satisfaction of the customer ${ }^{14}$. The quality of service has positive correlation with the pleasant behavior and has negative correlation with the unpleasant behavior ${ }^{15}$. Service quality is an attitude that determined by customer's perception on the quality of service in which there are differences of public banks customers and sharia banks customers $^{16}$. The quality of service is good when it can fulfill or exceed the customer's expectation $^{17}$. If the has bank provided services that do not meet the expectation of the customers, then that bank did not give a good qualified service. This can cause the dissatisfaction of the customers. If bank has provided the

12 Cronin, J. Joseph Jr. and Taylor, Stevent A. 1992. Measuring Service Quality: A Reexanination and Extention. Journal of Marketing. Vol. 46. 1992. 55.

${ }^{13}$ Zeithaml, Valerie A., and Bitner, Mary Jo. 1996. Services Marketing. (1 ${ }^{\text {st }}$ edition New York: McGrawHill International Editions, 1996), p. 123.

${ }^{14}$ Fomell C, MD Johnson, EW. Anderson, Jaesung Cha and B. Everin Bryant. The American Customer Satisfaction Index: Nature, Purpose and Findings. Journal of Marketing. Vol. 60 No. 10. 1996, 7.

${ }^{15}$ Parasuraman, V., A. Zeithaml and L. L. Beny. The Behavioral Consequences of Service Quality. Journal of Marketing. Vol. 40. 1996. p. 31.

${ }^{16}$ Kadir, Abd. Rahman. Pengaruh Komitmen Manajemen Bank Terhadap Tingkat Kepuasan Kerja Karyawan dan Tingkat Kepuasan Nasabah di Sulawesi Selatan. Disertasi (Surabaya, Universitas Airlangga, 2001), 144.

17 Said, Sudirman. Pengaruh Kemampuan Mengolah Informasi Terhadap Loyalitas Nasabah Bank Rakyat Indonesia (BRI) di Sulawesi Tenggara. Disertasi (Surabaya, Universitas Airlangga, 2004), 112. 
services that met the expectation of the customers, then the customers' satisfaction would be met. The quality of service influenced the customers' satisfaction $^{18}$. Another study states that the level of customers' satisfaction is influenced by the dimensions of service quality, especially, the assurance dimension. Even though this is slightly different with what has been found in this study that the level of customers' satisfaction is mainly influenced by the service quality dimensions, especially the dimension of responsiveness ${ }^{19}$.

The customers' trust significantly influenced the customers' satisfaction toward the Mandiri Sharia Bank. The higher the customers' trust to the services provided by the Mandiri Sharia Bank, the more satisfied those customers toward the services provided. In other words, the better the past experience, information and customers' enthusiasm, the overall satisfaction, the better the confirmation of expectation and comparison of ideal will be. In addition to the quality of service, another factor that influences the customers' satisfaction is trust. Trust is a critical factor for the customers in selecting which bank to save their money. In realizing this situation, the bank has to be able to gain the customers' trust that the bank where they save their money is a secure bank, thus, it would create customers' satisfaction. Trust is a belief that the bank can use as the mean to develop a long term relationship with the customers that the bank are serving. Trust is a willingness or faith between partners to develop a long term relationship in order to create positive outcome ${ }^{20}$. Trust is the business foundation. Earning the customers' trust is a way to create and maintaining customers. Trust is an individual willingness to depend his/herself on others and get involved in an exchange process because that individual has faith on that other parties ${ }^{21}$.

${ }^{18}$ Bei, Lien-T. and Chiao, Yu-Ching. An integrated model for the effects of perceived product, perceived service quality, and perceived price fairness on consumer satisfaction and loyalty. Journal of Consumer Satisfaction, Dissatisfaction and Complaining Behavior. Vol. 14, 2001, p. 125.

19 Natalisa, Diah. Pengaruh Komitmen Manajemen Terhadap Kualitas Layanan Untuk Meningkatkan Kepuasan Nasabah Maskapai Penerbangan Domistik Sudut Pandang Nasabah dan Penyaji Jasa. Disertasi. (Surabaya., Pascasarjana Universitas Airlangga, 2000), 98.

20 Gatot Yulianto, Purwanto Waluyo. Pengaruh Keefektifan Komunikasi, Kualitas Teknikal, Kualitas Fungsional dan Kepercayaan Pada Komitmen Keterhubungan Bandara Ahmad Yani Semarang, Telaah Manajemen, Magister Manajemen STIE Stikubank Semarang, Vol.1 No. 3. 2004, p. 349.

${ }^{21}$ Sharma, N., \& Patterson, P. G. Switching costs, alternative attractiveness and experience as moderators of relationship commitment in professional, consumer services. International journal of service industry management, Vol. 11 No. 5, 2000, h. 470. 
Customers trust is all knowledge own by the customers and all conclusion the customers made on the attributes and functions of an object ${ }^{22}$. The analysis on the characteristics of the Mandiri Sharia Bank showed that the majority of the customers' of the Mandiri Sharia Bank are male, aged above 40 years and married. The education level of the customers is mostly university graduates and mostly work in private companies and their average transaction is above IDR. 1,000,000 per month. They have been the customers for more than two years and most of them are also the customers of other banks. Based on these characteristics it can be concluded that the customers of the Mandiri Sharia Bank are mostly from the haves groups and know how to compare the banking services that they received. The customers' trust toward the bank is defined as customers' willingness to rely on the bank toward the risks that they might face. The expectation toward the bank can bring positive result ${ }^{23}$. Trust is defined as perception toward the reliability of the banks based on experiences, or more to the sequence of transaction or interaction characterized by the fulfillment of expectation toward the service performance and satisfaction ${ }^{24}$.

Trust is so important and benefits in developing the trust even though to be the trusted parties are not such an easy thing and it needs lots of cooperation. Factors that influence trust are: ${ }^{25} 1$ ) value which is a basic thing in developing the trust. The parties involved in a relationship have the same behavior, objectives and policy that would influence the ability to develop trust. 2) Reliance on other parties. To minimize the risk of untrusted parties to develop a relationship with the trusted parties. 3) Open and regulated communication. Communication that are made to develop trust has to be done regularly and of high quality or in other words, the communication has to be relevant and on time. Positive past communication would create trust and in turn would be a better communication.

Customers' give a good score toward the customers' trust. This is proven by the high level of appreciation given by the customers for each indicators of customers' trust, in which the average score given by the customers in sequence were $4.43,4.13$. Customers' trust is a sense of security in the interaction process

${ }^{22}$ Mowen, John C dan Michael Minor. Perilaku Nasabah. (Jakarta Jilid Satu Edisi Kelima. Alih Bahasa Lina Salim.: Erlangga, 2002), 312.

${ }^{23}$ Zboja, J. J., \& Voorhees, C. M. The impact of brand trust and satisfaction on retailer repurchase intentions. Journal of Services Marketing, Vol. 20 No. 6, 2006, p. 381.

24 Pantja Djati dan Erna Ferrinadewi. Pentingnya karyawan dalam pembentukan kepercayaan Nasabah terhadap bank jasa:(suatu kajian dan proposisi). Jurnal Manajemen dan Kewirausahaan. Vol 6, No.2. 2012, p. 117.

${ }^{25}$ Peppers, Don dan Rogers, Martha. Managing Customer Relationships: A Strategic Framework. (USA: John Wiley and Sons, Inc., 2004), p. 45. 
toward something that intended so it would bring positive and beneficial outcome for the customers. The trust is shown by honesty, good deeds, and competency ${ }^{26}$. From those three things, it is possible to develop trust for the customers that would result the long-term relationship between the bank and the customers. The bank needs the customers' trust to raise the customers' satisfaction. If the customers have high level of trust, then their satisfaction would also be high. In reverse, if the customers' trust is low, then their satisfaction will also be low. Trust has positive influence toward the customers' satisfaction. Trust is a faith that other's action would be consistent with their trust. Trust emerges from a gradual process which later accumulated in a form of trust $\mathrm{t}^{27}$. The customers' trust could be explained through the dimensions of: past experience, information and enthusiasm. The customers' trust depend on the customers' experience in consuming the goods or service and that they receive a good information from the bank. Customers' trust can be seen from the responds or from their feedback toward and information delivered by the bank staffs ${ }^{28}$. Enthusiasm or customers' attachment is a positive feedback shown by the customers toward the products or services that they receive. Other research showed the existence of influence of Islamic product attributes, religious commitment, service quality and trust toward the satisfaction and the loyalty of the Sharia Banks customers ${ }^{29}$.

Customers' commitment insignificantly influenced the customers satisfaction toward the Mandiri Sharia Bank. This research was conducted in the Jawa Timur Province where most of its population are Moslems. However, this does not guarantee the customers' satisfaction toward the Mandiri Sharia Bank. This is also inseparable from the fact that most of the respondents are those with the high level of educational background. The respondents are more real and has unclouded judgment in viewing the satisfaction toward the services of a particular bank. Customers viewed satisfaction as the main goal in comparing the commitment of the customers toward their religion. Religion does contain all the best things needed by the human being in managing their objectives and goals in life. Religion provides the goal of happiness and welfare, morality, work ethics, fairness management and everything that the human being needed in their

${ }^{26}$ Rakhman, A., Farida, N., \& Listyorini, S. Pengaruh Kualitas Layanan dan Kepercayaan terhadap Loyalitas Nasabah dengan Kepuasan Nasabah sebagai Variabel Intervening Studi Pada Nasabah CV. AHASS Brahma Motor. Jurnal Ilmu Administrasi Bisnis, Vol. 3 No, 4, 2014, p. 57-69.

${ }^{27}$ Rahman El Janusi, Pengaruh Atribut Produk Islam, Komitmen Agama, Kualitas Jasa Dan Kepercayaan Terhadap Kepuasan Dan Loyalitas Nasabah Bank Syariah; Pada Bank Muamalat Kota Semarang (Jurnal, Annual Conference on Islamic Studies (ACIS), 2-5 November 2009, Surakarta).

${ }^{28}$ Ibid

${ }^{29}$ Ibid 
interaction with other beings and other elements in the nature ${ }^{30}$. Religious commitment is one form of obedience toward the religious teaching. For the Moslems, Islam is a way of life that regulates all aspects of life, and in line with the Allah's command, "Oh you who believe! Enter perfectly in Islam (by obeying all the rules and regulations of the Islamic religion..." (QS. Al-Baqarah 208).

Commitment is a psychological condition that globally represents the dependence on a relationship; commitment summarizes the past dependence experiences and direct the reaction toward a new situations ${ }^{31}$. Commitment is a long-term orientation in a relationship, including the willingness to sustain that relationship. For the business with high level of competition, this implies that the banks' ability to create a long-term relationship with its customers is not only determined by that bank's actions but also determined by the competitors' actions. Bank that can successfully differentiate itself from its competitors may have better chance in creating relationship compared to the other banks. In reverse, the loyal customers that do not have better alternative is a vulnerable situation and only limited to the situation in which the customer's felt that she/he is trapped.

According to Peppers and Rogers, there are two different types of commitment, calculative and affective commitment. ${ }^{32}$ Calculative commitment is related to the type of instrument of that commitment and as the extension of the needs to hang on to the relationship caused by the economic benefits and the switching cost. The calculative commitment is caused by the economic analysis of the cost and benefit of making the commitment. Meanwhile, affective commitment is a result of someone who has emotional attachment and not economic reason. Calculative commitment is negatively related to trust and based on the calculation of cost and benefit. This type of commitment is not conducive for a long term relationship. On the other hand, the affective commitment which is based on the sustainable relationship, and not due to the short term economic benefit, but due to the each party feels emotional attachment or psychological ties with one another. Affective commitment positively related to trust and supports

${ }^{30}$ Iggi H. Achsien, Investasi Syariah di Pasar Modal (Jakarta: Gramedia Pustaka Utama, 2000), p. 8

${ }^{31}$ Rahman El Janusi, "Pengaruh Atribut Produk Islam, Komitmen Agama, Kualitas Jasa Dan Kepercayaan Terhadap Kepuasan Dan Loyalitas Nasabah Bank Syariah; Pada Bank Muamalat Kota Semarang" (Jurnal, Annual Conference on Islamic Studies (ACIS), 2-5 November 2009, Surakarta).

${ }^{32}$ Endang Sulistya Rini, "Pengaruh Economic Content, Resource Content, dan Social Content terhadap Kepercayaan, Kepuasan dan Komitmen serta Relationship Intention Debitur Bank Sumut di Sumatera Utara" (Disertasi, Program Pascasarjana Universitas Airlangga. Surabaya, 2007), p. 47. 
the benefit of a relationship for a longer period of time, and lowering the chance of conflict, and the intention to solve the conflict peacefully.

This research result supports the research conducted by the Bank of Indonesia. The factors that motivate the community to use the sharia banking service for the community in Jawa Timur and Jawa Barat are dominantly caused by the service quality and the nearness of the bank location with the center of activities, meanwhile the religious commitment is not one of the important factor that influenced the tendency to use the sharia banking services. However, for the people in Jawa Tengah, the religious factor is the most important consideration in using the sharia bank services. ${ }^{33}$. It has to be acknowledged that sharia banks in Indonesia are well developing, however, there are still many obstacles in developing the sharia banks, such as: (1) community's understanding that were still insufficient to understand the operational activities of the sharia banks, (2) the banking regulation that still not fully accommodating the operation of the sharia banks, (3) the office network of the sharia banks that still not wide enough, (4) the human resources who have qualification and skills in sharia banking are still very limited ${ }^{34}$. Even though in Islamic ethics in the marketing have been widely done, especially in the community economic activities, however, there are many questions remains on the existence of such services in the ever growing complexity of the today's community.

The quality of the services significantly influenced the customers' loyalty toward the Mandiri Sharia Bank. This means that the better the quality of service provided by the Mandiri Sharia Bank, the more loyal the customers of the Mandiri Sharia Bank would be. If the tangibles, reliability, empathy, responsiveness, and cooperation are better, the more improved the trust, emotional commitment, and cooperation. The customers of the Mandiri Sharia Banking are more critical toward the problems related to the banking services. Therefore, before deciding to be loyal to a bank, the customers need to know the quality of services provided by that particular bank. The bank is needed to be managed with cautious principles, as an institution whose function and existence is also critical for the community, the bank needed to be treated with cautiousness by all the other parties. The trusted bank is a stable bank. However, the Mandiri Sharia bank is kept trying to provide the best efforts and tries to increase the quality of their banking services in order to earn the sympathy of the customers and in order for the customers to remain loyal to the Mandiri Sharia bank as their first choice bank.

33 Bank Indonesia, Ringkasan Pokok-pokok Hasil Penelitian; Potensi, Preferensi, dan Perilaku Masyarakat Terhadap Bank Syariah di Pulau Jawa (Jakarta: Direktorat Penelitian dan Pengaturan Perbankan, 2000), p. 1

${ }^{34}$ Muhammad Syafii Antonio, Bank Syariah dari Teori ke Praktek (Jakarta: Gema Insani. 2001), p. 224. 
The Influence of Service Quality, Religious Commitment and Trust on The Customers' Satisfaction and Loyalty and Decision to Do The Transaction in Mandiri Sharia Bank of Jawatimur

This research supported the result of Bloemer et., al which stated that there are causality relationship between the quality of service and the satisfaction toward the customers' loyalty ${ }^{35}$. The quality of service gives significant influence toward the customers' loyalty. The customers' satisfaction significantly influence in mediating the relationship between the service quality and the customers' loyalty. Customers' satisfaction is also significantly functioned as moderator for the influence that happened between the quality of service and customers' loyalty ${ }^{36}$. Quality of service gives significant influence toward the direct and indirect loyalty of the customers with the mediation of the customers' satisfaction ${ }^{37}$. Perception of the service quality directly influences the customers' loyalty ${ }^{38}$. The customers that did not experience the service problem have higher level of loyalty and have lower external respond toward other products ${ }^{39}$. Among the customers that experienced problems in services, it was significantly proven that the customers' that received satisfying solution have higher loyalty and higher willingness to pay, and have lower willingness to switch to other products and they also have lower respond toward the external offered compared to those that did not meet the good solution in service problems.

This study is in contrast with the study conducted by Cronin and Taylor which stated that the quality of service has small influence over the decision to repeat banking transaction compared to the customers' satisfaction ${ }^{40}$. So the improvement of service quality would only increase the customers' satisfaction but is not able to make the customers to become loyal and repeat their banking transaction toward the banking services offered by the bank. The result of this study supports the study conducted by Bei and Chian which stated that the quality of service indirectly influenced the customers' loyalty mediated by the

${ }^{35}$ Bloemer, Josee., Ko de Ruyter and Pascal Peeters. Investigating drivers of bank loyalty: the complex relationship between image, service quality and satisfaction. The International Journal of Bank Marketing. Vol. 16. 1998, p. 276.

${ }^{36}$ Fullerton, G., and Taylor S. Mediating, interactive and Non-Linear Effect in Service Quality and Satisfaction with Service Research. Journal of Marketing. Vol. 46, 2002, p. 55.

${ }^{37}$ Caruana, Albert. 2002. Service Loyalty. The Effect of Service Quality and The Mediating Role of Customer Satisfaction. European Journal of Marketing. Vol. 36. 2002, p.. 811.

${ }^{38}$ Said, Sudirman. Pengaruh Kemampuan Mengolah Informasi Terhadap Loyalitas Nasabah Bank Rakyat Indonesia (BRI) di Sulawesi Tenggara. Disertasi (Surabaya, Universitas Airlangga, 2004), 112.

${ }^{39}$ Parasuraman, V., A. Zeithaml and L. L. Beny. The Behavioral Consequences of Service Quality. Journal of Marketing. Vol. 40. 1996. p. 31.

${ }^{40}$ Cronin, J. Joseph Jr. and Taylor, Stevent A. 1992. Measuring Service Quality: A Reexanination and Extention. Journal of Marketing. Vol. 46. 1992. 55. 
customers' satisfaction ${ }^{41}$. This shows that there is no direct and significant correlation between the quality of service and the customers' loyalty. The existed relationship is an indirect relationship mediated by the customers' satisfaction.

Customers' satisfaction significantly influenced the loyalty of the customers toward the Mandiri Sharia Bank. This bank is a bank that oriented to the customers' trust. This trust is related to the credibility of the bank in the eye of the customers. Trust is earned from a long process until both parties involved trust each other. If the trust is installed between the bank and the customers, then the effort to cooperate would be easier and beneficial for both parties. From the bank side, this would create the customers loyalty that is very crucial for the existence of the bank. The benefit of the trust for the customers is that the customers can obtain the appropriate product and it will create the satisfaction toward the banking products and minimize the risks of dissatisfaction toward the bank products that the customers are using ${ }^{42}$. In order to develop loyalty of the customers, the Mandiri Sharia Bank has to earn the trust of the customers and increase the customers' satisfaction of the service that the bank provides. In winning the competition, the bank has to earn the customers' trust in providing services for their customers; therefore, the existence of this trust will increase the customers' loyalty.

The aspects that influenced the customers' loyalty are: (1) satisfaction, comparison between the expectation before commencing transaction with the performance felt during the transaction. (2) Emotional bonding, the customer feel the strong connection with other customers that are also using the same product or service. (3) Trust, someone's willingness to trust the bank to run certain function. (4) Choice reduction and habit, transaction of a product regularly as the accumulation of experience or repetition. (5) History with company ${ }^{43}$, someone's experience toward the bank that forms his/her behavior. Good services from the bank will resulted in the repetition of the behavior toward that bank.

In this research, improvement of the customers' trust would finally increase the customers' loyalty. The banking institutions are very dependent on community's trust. Without trust from the community, bank would not be able to run its business properly. It is imperative for the bank to be trusted by the community for them to be save their money in that bank. In banking law, there

${ }^{41}$ Bei, Lien-T. and Chiao, Yu-Ching. 2001. An integrated model for the effects of perceived product, perceived service quality, and perceived price fairness on consumer satisfaction and loyalty. Journal of Consumer Satisfaction, Dissatisfaction and Complaining Behavior. Vol. 14, 2001, p. 125.

${ }^{42}$ Siburian, Ind Tigana Prasetyo. Pengaruh Kualitas Layanan dan Kepuasan Nasabah terhadap Loyalitas Nasabah pada Bank Mandiri Semarang. Jurnal Ilmu Administrasi Bisnis. 2000, p. 1.

${ }^{43}$ Zikmund, W.G. Business Research Methods, (7th Edition. South Western, Thomson, 2003), . p. 72 
The Influence of Service Quality, Religious Commitment and Trust on The Customers' Satisfaction and Loyalty and Decision to Do The Transaction in Mandiri Sharia Bank of Jawatimur

are several banking principles, one of them is trust. Trust is a principle, in which the relationship between the bank and its customers is based. The bank runs its business using the community's money based on trust, therefore, every banks need to ensure that their banks are healthy by maintaining the community's trust.

This research is relevant with Wagner and Rydstorm in which, they found that customers, trust and commitment are the main mediators in influencing the behavior intention compared to the overall satisfaction ${ }^{44}$. Trust is a construct that reflects credibility, in which, the ability to influence the long term orientation of the customers by minimizing the perception of risk related to opportunistic actions of the bank ${ }^{45}$. The bank need to earn the customers' trust. Customers' trust influenced the loyalty toward the bank ${ }^{46}$. The customers' trust is needed by the bank to create the customers' loyalty toward that bank. The loyal customers tend to repeat their transaction and to look for their needs to be fulfilled by the bank that they trust. The bank need to maintain this loyalty because maintaining the customers' loyalty means the sustainability of the bank's livelihood. There are several factors that influencing the customers' loyalty toward the bank, such as, satisfaction, trust, and the commitment from the customers themselves. In other words, the customers' trust toward a particular bank would be able to move their loyalty toward that particular bank.

Customers' trust toward a bank would improve the value of a good relationship with the bank. Therefore, it would also increase the possibility of customers to repeat their consumption of a particular bank service. The high level of trust would influence in a way that it lessen the possibility of that customers to switch to other bank ${ }^{47}$. The relationship behavior between the bank and the customers would be much depend on the trust and commitment ${ }^{48}$. Trust would be positively related to the intention to repeat the transaction or loyalty. Customers'

${ }^{44}$ Janet Wagner and Gabrielle Rydstrom. Satisfaction, Trust and Commitment in Consumers = Relationships With Online Retailers", in E - European Advances in Consumer Research Volume 5, eds. Andrea Groeppel-Klien and Frank-Rudolf Esch, Provo, UT: Association for Consumer Research, Vol. 5, 2001, p. 276.

${ }^{45}$ Aydin, S. \& Özer, G. 2005. How switching costs affect subscriber loyalty in the Turkish mobile phone market: An exploratory study. Journal of Targeting, Vol. 14 No. 2, 2005, p. 141.

${ }^{46}$ Chumpitaz, Ruben dan Paparoidamis, Nicholas. Service quality, relationship satisfaction, trust, commitment and business-to-business loyalty, European Journal of Marketing. Vol. 41 No. 7, 2007, p. 836.

47 Suhardi, Gunarto. Faktor-Faktor yang Mempengaruhi Kepercayaan dan Loyalitas Nasabah Perbankan Di Surabaya. Jurnal Kinerja. Vol. 10 No.1, 2006. p.10.

48 Setiawan, Mulyo Budi \& Ukudi. 2007. Pengaruh Kualitas Layanan, Kepercayaan dan Komitmen terhadap Loyalitas Nasabah. Jurnal Bisnis dan Ekonomi. Vol 14 No.2, 2007, p. 215. 
trust has positive influence toward the loyalty to repeat the transaction and to intensify the transaction. The relationship between the customers' trust reflects all the knowledge possessed by the customers and the entire conclusion made by the customers related to an object, attributes, and its benefits. The trust toward an object, attributes, and its benefits showed customers' transaction toward a bank and therefore, generally, a customer's trust would be difference from another customer's, in which, the higher the trust, the higher the customers' loyalty.

Customers' religious commitment influenced the customers' loyalty toward the Mandiri Sharia Bank. The customers generally give good assessment toward the religious commitment. This is proven by the high appreciation or customers' valuation for each customers' religious commitment indicators of 4.354. The good religious commitment influences the customers' loyalty. The average point given by the customers for the customers' loyalty was 4.368. Religious commitment is characterized by the strong willingness to implement religious rules, beliefs and strong acceptance toward the religious values. Religious commitment influenced the loyalty toward the Sharia Bank ${ }^{49}$. Religious commitment is needed by the human being to manage their life goals and objectives. Religious commitment provide ultimate goals of happiness and prosperity, morality, work ethics, equality and equity management, and everything else needed by the human beings in their interaction with each other, and with all the elements of nature.

Religious commitment creates an order of life, in which, there are no parties that can dominate over other parties, even though, each parties, have different religion, sex, and backgrounds ${ }^{50}$. On the other hand, Rahman El-Janusi defines religious commitment as manifestation of obedience of religious values ${ }^{51}$. Religious commitment shows the extent to which someone is committed and obeyed his/her religious values. Religious commitment generally refers to someone's attitude toward religion in general, not toward one specific aspect of religion. Specifically, it is one's intensity to implement his/her religious teaching.

49 Rahman El Janusi, "Pengaruh Atribut Produk Islam, Komitmen Agama, Kualitas Jasa Dan Kepercayaan Terhadap Kepuasan Dan Loyalitas Nasabah Bank Syariah; Pada Bank Muamalat Kota Semarang" (Jurnal, Annual Conference on Islamic Studies (ACIS), 2-5 November 2009, Surakarta).

50 Wasid Mansyur, "Agama Konstektual dan Kemaslahatan Umat", http://pesma.sunan-ampel.ac.id/?p=18, diunduh tanggal 11 September 2014, jam 21.30.15

51 Rahman El Janusi, "Pengaruh Atribut Produk Islam, Komitmen Agama, Kualitas Jasa Dan Kepercayaan Terhadap Kepuasan Dan Loyalitas Nasabah Bank Syariah; Pada Bank Muamalat Kota Semarang" (Jurnal, Annual Conference on Islamic Studies (ACIS), 2-5 November 2009, Surakarta). 
Religious commitment is a basis for the Islamic community to chose the bank, in which they do their economic transaction.

The relationship of religious commitment and loyalty can be stated that the religious commitment related to the visible and invisible activities. Visible activities such as, muamalah activities (economic activities), muasyaroh (social activities), dakwah (promoting the good deeds and prohibiting the bad deeds) ${ }^{52}$. The customers with high religious commitment would not do their economic activities, social activities, or their Islamic syiar randomly. These kinds of customers highly believed that all their activities should be in line with the religious teaching or syar'i. These kinds of customers would tend to be loyal to sharia banks based on their religious beliefs, without considering or comparing the quality of services of that bank to other banks, customers with high level of religious commitment would be directly loyal and would not switch to other banks. Loyalty is characterized by on-going and regular transaction and recommending that sharia bank to their colleagues or the members of their religious activities.

Invisible activities of the customer with high religious commitment happen inside their minds. The practical dimensions covered their obedience behavior and their fanaticism toward the religious indoctrination, which are shown through their commitment toward the religious indoctrination. The consequences would be visible in the customers' daily lives. The actualization of the customers religious values are internalized and integrated into all aspects of their lives. Automatically, the customers with high religious commitment would be fanatic toward the sharia banking products. This fanaticism toward the sharia banking products is a manifestation of religious indoctrination that they practice in their daily lives ${ }^{53}$.

Customers' satisfaction significantly influenced the customers' loyalty toward the Mandiri Sharia Bank. This means that the more satisfied the customers toward the services provided by the Mandiri Sharia Bank, the more loyal they would be toward the products and services of the Mandiri Sharia Bank. This loyalty attitude of the customers is influenced by their belief, emotion and satisfied feelings, as well as the expectation of the customers themselves. In addition to that, the bank has to be able to transform this satisfied feeling into happiness. For the bank, this is a challenge to create a special, beneficial, and long-term relationship between the bank and its customers. Personal approaches conducted by the bank to enable them to listen and find out whether the services

52 Dewi Sartika, Ali Mubarok, Indari Laasati. Hubungan antara Religius Commitment dengan keputusan menggunakan jasa Bank Syariah pada Dosen Unisba. Jurnal Ilmu Sosial, Ekonomi dan Humaniora. Vol. 6 No. 2. 2011, h. 23.

${ }^{53}$ ibid 
and products that they are offering has met needs/expectation of the customers as well as to quickly responds to the demands and complaints from the customers.

The study conducted by Bouldinget al., stated that the loyalty of the customers were due to accumulated satisfaction/dissatisfaction over a period of time in addition the product's quality ${ }^{54}$. Loyalty would be formed due to the habit and long history of consumption of particular banking products. Characteristics of customers based on the length ot time they have had been customers of Mandiri Sharia Bank was dominated by the long-time customers, in which, almost $93 \%$ of the customers are the customers that have been customers and have relationship with the Mandiri Sharia Bank customers for more than two years. This shows that the customers of the Mandiri Sharia Bank are loyal customers, which is proven by their repeated transaction of products and services of Mandiri Sharia Bank that they have felt.

Bank which can provide long term satisfaction makes the customers loyal and repeat their banking transaction. There is relationship between service quality and customers satisfaction toward the customers' loyalty ${ }^{55}$. Customers' loyalty significantly influenced the willingness to buy and the quality of services has smaller influence toward the repeated transaction compared to the customers' satisfaction $^{56}$. This study revealed that customers' satisfaction influenced the customers' loyalty, which is defined as willingness to repeat transaction. If the customers valued a product or service could give additional value for the customers then the customers would be satisfied with the service or products offered $^{57}$. This condition would create an emotional tie or relationship between the bank and the customers. This emotional relationship is called loyalty of the customers toward the bank.

Customers' satisfaction is an evaluation toward an inherent surprise attached to the acquisition of a product and consumption experience ${ }^{58}$. But it has also to be kept in mind that the customers' expectation is formed based on the past transaction experience, colleagues' comments, as well as the promises made

${ }^{54}$ Boulding, W., Staelin Kalra, and Zeithaml. V., A. A Dynamic Process Model of Service Quality: From Expectations to Behavior Intentions. Journal of Marketing Research. Vol. 30, 1993,p. 7.

${ }^{55}$ Bloemer, Josee., Ko de Ruyter and Pascal Peeters. Investigating drivers of bank loyalty: the complex relationship between image, service quality and satisfaction. The International Journal of Bank Marketing. Vol. 16. 1998, p. 276.

${ }^{56}$ Cronin, J. Joseph Jr. and Taylor, Stevent A. Measuring Service Quality: A Reexanination and Extention. Journal of Marketing. Vol. 46. 1992. 55.

${ }^{57}$ Butz, Howard E. Jr. and Goodstein, Leonard D. Measuring Customer Value: Gaining The Strategic Advantage. Journal Organizational Dynamics.Vol. 24, 1996, h. 6.

${ }^{58}$ Oliver R. L. Measurement and Evaluation of Satisfaction Process in Retail Setting. Journal of Retailing. Vol. 1981, p. 25. 
The Influence of Service Quality, Religious Commitment and Trust on The Customers' Satisfaction and Loyalty and Decision to Do The Transaction in Mandiri Sharia Bank of Jawatimur

by the marketing people and their competitors. Customers' satisfaction influenced the customers' loyalty ${ }^{59}$. Customers' satisfaction significantly plays a moderator role for the influence between the qualities of service toward the customers' loyalty ${ }^{60}$. Quality of service has significant influence toward the customers' loyalty, directly and indirectly, through the mediation of the customers' satisfaction ${ }^{61}$. Customers' satisfaction directly influenced the customers' loyalty ${ }^{62}$. Satisfaction is a signal of true loyalty ${ }^{63}$. Loyal customers are those who are highly satisfied with particular banking products, thus it makes them enthusiast in introducing the products to whomever they met ${ }^{64}$.

This research is in line with the previous research, which stated that there was a positive and significant relationship between the commitment toward religion and loyalty of customers who used the Islamic banking services in Morocco. Customers with high religious commitment are characterized by the high frequency of attending the religious activities, intensity of the discussion related to religious matter and often spare their time for the religious life with their families would prefer and related to using the Islamic banks services to other banks. Religious commitment urges someone to do all his/her economic activities usng the services of Islamic banks ${ }^{65}$. Religious commitment is the reason behind someone is always loyal and using the sharia banks in his/her daily life.

${ }^{59}$ Bei, Lien-T. and Chiao, Yu-Ching. An integrated model for the effects of perceived product, perceived service quality, and perceived price fairness on consumer satisfaction and loyalty. Journal of Consumer Satisfaction, Dissatisfaction and Complaining Behavior. Vol. 14, 2001, p. 125.

${ }^{60}$ Fullerton, G., and Taylor S. Mediating, interactive and Non-Linear Effect in Service Quality and Satisfaction with Service Research. Journal of Marketing. Vol. 46, 2002, h. 55.

${ }^{61}$ Caruana, Albert. 2002. Service Loyalty. The Effect of Service Quality and The Mediating Role of Customer Satisfaction. European Journal of Marketing. Vol. 36. 2002, p.. 811.

62 Said, Sudirman. Pengaruh Kemampuan Mengolah Informasi Terhadap Loyalitas Nasabah Bank Rakyat Indonesia (BRI) di Sulawesi Tenggara. Disertasi (Surabaya, Universitas Airlangga, 2004), 112.

${ }^{63}$ Astuti, Sri Wahyuni. 2001. Dampak Pemasaran Jasa Rumah Sakit Terhadap Nilai, Kepuasan dan Loyalitas Pasien. Penelitian Pada Pasien Rawat Inap Rumah Sakit Umum di Tiga Ibu Kota Propinsi di Pulau Jawa. Disertasi. (Surabaya, Universitas Airlangga, 2001), 74.

${ }_{64}^{64}$ Tjiptono. Pemasaran Jasa. (Malang: Bayumedia, 2004), p. 387.

65 Abdelghani Echchabi dan Hasanuddeen Abd Aziz. The Relationship Beetween Religiousity and Customer Adoption of Islamic banking Services in Marocco, Oman. Arabian Journal of Business and Management Review, Vol. 1. No. 9, 2012. p. 87. 
Service quality significantly influenced the decision to repeat the banking transaction using the services provided by Mandiri Sharia Bank. The relationship between the qualities of service toward the decision to repeat banking transactions can be explained through the indicators of variable, which covered the quality of services. Reliability indicator is an ability of the bank to provide services as timely and satisfactorily promised. The relationship between services' quality and decision to make transaction can be said that a product or service has impact on the willingness to use the same services in the future. Because basically, past behavior can directly influences future interest and behavior. Therefore, the quality of service is a baseline in determining the decision to repeat a transaction or not for a user of a service, from the quality of service, performance would be assessed and satisfaction can be felt of the services provided by the bank.

The relationship between the quality of service and buying interest can be explained that the good quality of service would encourage the buying interest of the customers ${ }^{66}$. If the bank is able to provide qualified services, such as the appropriate introduction of services, comfortable outlets, and appropriate services, are expected to encourage the customers to repeat their transaction. This result supports the Cronin and Taylor study, which stated that the quality of service had small influence toward the repeated transaction ${ }^{67}$. Quality of service is a level of condition in which the good or bad presentation provided by the seller in order to satisfy the customers through providing the needs or demands beyond what is expected by the customers ${ }^{68}$. In this research, it was revealed that the perception toward quality had impact toward the buying interest of the customers. Customers' perception toward the quality of services provided by the bank had significant impact toward the customers' decision to repeat their banking transaction in that particular bank ${ }^{69}$.

${ }^{66}$ Rahma, E. S. (2007). Analisis Pengaruh Kualitas Layanan dan Citra Merek terhadap Minat Beli dan Dampaknya pada Keputusan Transaksi (Studi pada Pengguna Telepon Seluler Merek Sony Ericson di Kota Semarang) (Doctoral dissertation, Program Pasca Sarjana Universitas Diponegoro).

${ }^{67}$ Cronin, J. Joseph Jr. and Taylor, Stevent A. 1992. Measuring Service Quality: A Reexanination and Extention. Journal of Marketing. Vol. 46. 1992. 55.

${ }^{68}$ Tjiptono, Fandy \& Gregorius Chandra. 2011. Service, Quality \& Satisfaction Edisi 3. Yogyakarta: ANDI, p. 58

69 Bloemer, Josee., Ko de Ruyter and Pascal Peeters. Investigating drivers of bank loyalty: the complex relationship between image, service quality and satisfaction. The International Journal of Bank Marketing. Vol. 16. 1998, p. 276. 
The Influence of Service Quality, Religious Commitment and Trust on The Customers' Satisfaction and Loyalty and Decision to Do The Transaction in Mandiri Sharia Bank of Jawatimur

A service product has impact on the willingness to use the same product for the future ${ }^{70}$. The relationship between the customers and the bank would be stronger when the customers have good assessment toward the quality of service provided by the bank and vice versa, it would be weaker when the customers have negative assessment toward the quality of service provided by the bank ${ }^{71}$. Good assessment would resulted in a good willingness to do goo, such as preferences toward a bank (that provide good services) compared to other banks (that do not provide good services). Quality of service influenced the satisfaction and in turn, satisfaction influenced the buying interest. There is a direct relationship between quality of service with the buying interest. Perception toward the quality of service has significant impact toward the buying interest ${ }^{72}$.

Other research result stated that the quality of services, simultaneously, directly and indirectly, influenced the buying interest. ${ }^{73}$ The quality of service has direct impact for four or five researched industries ${ }^{74}$. The indication of the influence of service quality toward the buying interest is also in line with the research conducted by Kuntjara. His research indicates that the perception toward quality has influence toward the customers' buying interest $\mathrm{t}^{75}$.

Customers' trust significantly influenced the decision to repeat the transaction in Mandiri Sharia Bank. customers' trust toward the Mandiri Sharia Bank of Jawa Timur is related to the customers' experience in executing the transaction in Mandiri Sharia Bank of Jawa Timur. Most of the customers stated their confidence toward the bank after repeatedly do the banking transactions for quite a long period. The transaction that mostly selected by the customers are Savings in Indonesian Rupiah with the Mudharabah Mutlaqah agreement, which

${ }^{70}$ Olorunniwo, F., Hsu, M. K., \& Udo, G. J. (2006). Service quality, customer satisfaction, and behavioral intentions in the service factory. Journal of Services Marketing, 20(1), 59-72.

71 Singh, H. (2006). The importance of customer satisfaction in relation to customer loyalty and retention. Academy of Marketing Science, 60, 193-225.

${ }^{72}$ Cronin, J. Joseph Jr. and Taylor, Stevent A. 1992. Measuring Service Quality: A Reexanination and Extention. Journal of Marketing. Vol. 46. 1992. 55.

${ }^{73}$ Cronin, J. J., Brady, M. K., \& Hult, G. T. M. (2000). Assessing the effects of quality, value, and customer satisfaction on consumer behavioral intentions in service environments. Journal of retailing, 76(2), 193-218.

${ }^{74}$ Bei, Lien-T. and Chiao, Yu-Ching. 2001. An integrated model for the effects of perceived product, perceived service quality, and perceived price fairness on consumer satisfaction and loyalty. Journal of Consumer Satisfaction, Dissatisfaction and Complaining Behavior. Vol. 14, 2001, h. 125.

${ }^{75}$ Kuntjara, K. Analsis Faktor-faktor yang mempengaruhi minat Beli Ulag Nasabah (Studi kasus di PT Wijaya Karya Beton Wilayah IV; Jateng, DIY, Kalsel dan Kalteng), Disertasi, (Semarang, Unversitas Diponegoro, 2007), 69.. 
the withdrawal can be done according to certain agreed stipulation. In addition to that, the customers highly trust all the information given by the bank, therefore, the customers were so enthusiast in executing the repeated transactions. The important factor that influenced the willingness to repeat transactions is the trust factor. Trust becomes a key factor in every transaction. Only customers who trust the bank would repeat their transactions. Therefore, if there is no basic trust between the vendor and the buyer, there would be no transaction, especially if they know out that the product that sold or offered by the vendor are invisible, or the product is service ${ }^{76}$.

This research is in line with the research conducted by Macdonnal and Sharp in which they found that from several factors that influenced the decision to do transaction, customers' trust significantly has direct influence toward the decision to do transaction ${ }^{77}$. Other researchers said that privacy factors, trust and experience are proven to be the main factors that influenced the customers to repeat transactions ${ }^{78}$. Further, Chiu in his research stated that, in attracting the buyer interest, trust is an important factor because transaction demands a secure and trust from the customers in executing the transaction. The bank that wants the customers' to rebuy their products should pay attention to their reputation. This is due to the customers that also paying attention to the information of the banks and how his/her experience on using that particular bank services ${ }^{79}$. When the customer has good experience on consuming the product produced by a bank, then that customer would give a positive image toward the bank. Positive or good information about that particular bank is expected to add the customers' trust toward that bank. Further, it is expected that the customers would be willing to buy the products offered by the banks. Customers' behavior and trust influenced by their experience in the past. The customers' experience would repeat their transaction.

Customers' religious commitment significantly influenced the decision to repeat the banking transaction at Mandiri Sharia Bank. The customers viewed the religious commitment as relationship between human and God. In the community who upheld these religious values, the existence of Sharia banks is expected to

${ }^{76}$ Pavlou, P. A., \& Gefen, D. Building effective online marketplaces with institution-based trust. Information Systems Research, Vol. 15 No. 1, 2004, p. 37.

${ }^{77}$ Macdonald, E. K., \& Sharp, B. M. Brand Awareness Effects on Consumer Decision Making for a Common, Repeat Purchase Product:: A Replication. Journal of business research, Vol. 48 No. 1, 2000, p. 5.

${ }^{78}$ Baesens, B., Viaene, S., Van den Poel, D., Vanthienen, J., \& Dedene, G. Bayesian neural network learning for repeat purchase modelling in direct marketing. European Journal of Operational Research, Vol. 138 No. 1, 2002, p. 191.

${ }^{79}$ Chiu, C. M., Hsu, M. H., Lai, H., \& Chang, C. M. Re-examining the influence of trust on online repeat purchase intention: The moderating role of habit and its antecedents. Decision Support Systems, Vol. 53 No. (4), 2012 p. 835. 
The Influence of Service Quality, Religious Commitment and Trust on The Customers' Satisfaction and Loyalty and Decision to Do The Transaction in Mandiri Sharia Bank of Jawatimur

give the solution for the people who want to do their economic activities according to their beliefs, Islam. On the other hand, the behavior of the customers that is influenced by their religious commitment is also a business opportunity for sharia banking business that runs business without any interests. Sharia bank is a financial institution operated under the principal of Islamic law or sharia, especially in their ways of doing their economic activities. The main principle of the sharia financial institutions is free of interest, which is reflected in their products. The attribute of the Islamic products of the sharia banks are free of interest; the investment outcome is divided based on the outcome; avoiding the uncertainty; avoiding the gambling elements (maisir); halal investment; and conduct their activities according to the sharia principles.

Further, the researcher from the western world has tried to conduct research correlating the religious commitment toward the decision to buy back of the American community. Schiffman and Kanuk stated that the decision to do the transaction is the selection of two or more alternatives of buying decision. The customers' decision to do the transaction is influenced by the customers' behavior. The Jewish community in America considered their religious commitment is something important and therefore influenced their decision to buy a halal product to be consumed. Therefore, in their theory classified the religious commitment under the sub culture in giving the external influence in the decision making process of the customers. Moslem customers intend to consider the halal matter in deciding the product that they would consume ${ }^{80}$.

Other researchers have stated that religious commitment positively and significantly influenced the decision to buy a product. Religious commitment could influence the general attitude and behavior of customers ${ }^{81}$; especially in the decision to repeat the transaction in Mandiri Sharia Bank. The religious commitment is one of the most important cultural aspects to influence the customers' behavior. The influence of religious commitment toward the intention to buy or to transact and this behavior is only based on religious consideration ${ }^{82}$. Therefore, religious commitment is an important value in the cognitive aspects of

${ }^{80}$ Aisyah, Muniaty, Pengaruh Labelisasi Halal terhadap Keputusan Pembelin Produk Mie Instan Indofood, Etikonomi, Vol. 6, No. 2. 2007, p.1.

${ }^{81}$ Bonne, K., Vermeir, I., Bergeaud-Blackler, F., \& Verbeke, W. Determinants of halal meat consumption in France. British Food Journal, Vol. 109 No. 5, 2007, p. 367.

${ }^{82}$ Astogini, D., Wahyudin, W., \& Wulandari, S. Z. (2014). Aspek Religiusitas Dalam Keputusan Transaksi Produk Halal (Studi tentang labelisasi halal pada produk makanan dan minuman kemasan). Jurnal Ekonomi Bisnis dan Akuntansi (JEBA), Vol. 13 No. 1. 2014, p. 1. 
the customers in influencing the customers' trust. The relationship between the religious commitment and the decision to repeat the transaction can be explained from the following aspects of (1) religious rituals, the customers are obedience in implementing the religious commandment such as praying, fasting, paying the zakah/tax, and go to mecca to do Hajj. Religious rituals influenced the customers in selecting the bank. The decision to do transaction is based on the halal and haram aspect. The religious rituals are visible from the concrete matters such and directly related to the worship rituals, meanwhile the decision to do the transaction is related to the economic activities.

(2) Ideology, the customers have a very strong believe that islam is the most righteous religion and all the teaching taught by islam is good and should be the basis of guideline for all the aspects of life. The decision to do transaction in the bank should also be based on Islam. The belief that of the righteousness of Islam is the basis for the customers to select the sharia banks and the decision to do the transaction is perceived as economic activities that should be based on Islamic values. (3) The customers' experience in accepting the values of Islam are due to the indoctrination of Islamic values that they have gained through previous Islamic learning. The effort to add the knowledge about their religion is gained through seminars or reading religious books to add the essentiality of importance of halal in banking transaction (4) Consequences, the customers' decision to buy or to do transactions with the bank is based on the consequence that the person is a Moslem. The commitment to implement the Islamic teaching in his/her daily life, one of which, is through periodic and ongoing transactions with the sharia bank. The bank understands the market of its target. The customers that are generally perceived as having the religious commitment pay attention in their economic activities process in transaction decision or to do transaction through the sharia bank. Therefore, the customers are guaranteed to get the halalan toyyiban/halal and good banking services.

Customers' satisfaction significantly influenced the decision to repeat the transaction using the services provided by Mandiri Sharia Bank. Repeated transaction as a action to rebuy the same brand service or product is done by customers without any objection toward that product ${ }^{83}$. There are two possibilities that can cause someone to repeat the transaction or to rebuy a product. First, the customer was satisfied with the first transaction. Second, the customer was not satisfied, but he/she still does the same transaction. The second possibility is generally caused by their perception that the cost that they have to pay for switching to other vendor, to look for, evaluate and to adopt the services from other bank vendor is too high. Repeated transaction is an action of repeating the

${ }^{83}$ Hawkins, D. I., David L. Mothersbaug, dan Roger J. Best. 2007. Consumer

Behavior : Building Marketing Strategy. (New York : McGraw-Hill, 2007), 213. 
previous transaction after feeling satisfied with the previous transaction. If the customer is satisfied, then next, there would be a bigger possibility for her/him to repeat or rebuy the same product or service. There are three attributes of people who repeat their transaction, namely: the brand image, the product, and the effectiveness of advertisement (promotion).

Customer's behavior is a direct action involved in obtaining, consuming, spending product and services, including the process of needs before and after that action ${ }^{84}$. If the bank is paying attention to this customers' behavior, then the next step is formulation policy of marketing strategy related to the product. It can be assured that the customers would choose a better quality product compared to other banks. Producing qualified services is not such an easy thing. At least, the bank is maintaining and ensuring that that their quality of services is of standard. The success and failure of a bank is largely depending on the reaction of individual and groups that is manifested in transaction patterns, including repeated transaction. Someone's willingness to repeat a transaction shows that the person is interested due to many benefits of that transaction or if the customer is satisfied, then the customer would be more likely to rebuy that product. With the increase of people who execute banking transactions for various reasons and interests, customers willingness to repeat the transaction would also increase, thus, if the services are good, the customers would be satisfied.

The customers who are satisfied with certain banking services would tend to repeat the same transaction. Bank with its services attributes, would make the customers to rebuy the banking services provided by that bank. There are many researches discussed customers satisfaction, which agree that there is a positive correlation between the satisfaction and repeated transaction, in which, if the customers were satisfied of the services and products in the first time of the consumption, that customers would tend to repeat the consumption of those products or services. Customers' whole satisfaction influenced the repetition of transaction $^{85}$. If the bank is able to provide this satisfaction, then it is potentially that the bank to fulfill all the reasons for the customers to buy backs their services would increase, therefore, the possibility for the customers to use the services provided by the bank would also increase. With the repeated transaction in a bank and the bank is able to satisfy the customers, then there is a big for the customers

${ }^{84}$ Blackwell, R. D., Miniard, P. W., \& Engel, J. F. Consumer behavior (9th. South-Western Thomas Learning. Mason, OH, 2001.), 115.

${ }^{85}$ Jiang, P., \& Rosenbloom, B. Customer intention to return online: price perception, attribute-level performance, and satisfaction unfolding over time. European Journal of Marketing, Vol. 39 No. 1, 2005. p. 150. 
to show a regular and well-structured transaction decision process, thus it speeds up the decision making process for a transaction ${ }^{86}$.

Customers' loyalty significantly influenced the decision to repeat the transaction in Mandiri Sharia Bank. The commitment to buy back is the most important attitude for the loyalty and even more important than satisfaction. If there is no repeated transaction, then it is the signed of the absence of loyalty ${ }^{87}$. Motivation to rebuy comes from the high level of positive attitude toward particular product or services, compared to other similar products or services provided by other potential vendors. Repeated transaction is one of the behavior which followed the previous transaction based on satisfaction. If the customer is satisfied then she/he will show a bigger chance to rebuy the same product or service for the following occasion ${ }^{88}$.

Repeated transaction is a behavioral attitude of a customer, in which she/he only buys certain product or services repeatedly with approval factors in it, therefore the customer's loyalty is formed, which is a commitment toward certain brand, vendor, or bank based on the positive attitude reflected on the consistency of repeated transaction ${ }^{89}$. Loyal customers would do repeated transactions of a banking product that they use to buy, even the customers would not consider to buy the similar products from other bank. The advantage and disadvantage of the bank would be told to the bank, even these kinds of customers would spread the benefits of being a customer of the bank that they are loyal to other people ${ }^{90}$.

\section{Conclusion}

Theoretical findings that refers to the development of theoretical development in this research is that simultaneously, service quality and customers' trust influenced the satisfaction, loyalty, and decision to repeat banking transaction in Mandiri Sharia Bank. Customers satisfaction and loyalty are intervening variables that correlated between the quality of service and customers' trust in making the decision to repeat their transaction using the banking services provided by the Mandiri Sharia Bank. Meanwhile, the religious commitment insignificantly influenced the quality of service, however, it

${ }^{86}$ Bolton, R. N., Lemon, K. N., \& Verhoef, P. C. Expanding business-tobusiness customer relationships: Modeling the customer's upgrade decision. Journal of Marketing. Vol 72 No. 1, 2008. p. 46.

87 Griffin, Jill. Customer Loyalty, Menumbuhkan dan Mempertahankan Kesetiaan Nasabah. (Jakarta, Penerbit : Erlangga, 2005), 134.

${ }^{88}$ Kotler \& Armstrong. Marketing (9th ed. Pearson International Edition, 2009), p. 176.

89 Thejasukmana, V. A. Analisis Pengaruh Experiential Marketing Terhadap Transaksi Ulang Nasabah The Vinnette (House of Bovin and Lynnette) Surabaya. Jurnal Strategi Pemasaran. Vol. 2 No. 1, 2014, p. 1.

${ }^{90}$ Tjiptono. Pemasaran Jasa. (Malang: Bayumedia, 2004), p. 387. 
The Influence of Service Quality, Religious Commitment and Trust on The Customers' Satisfaction and Loyalty and Decision to Do The Transaction in Mandiri Sharia Bank of Jawatimur

significantly influenced the customers' loyalty and decision to repeat banking transaction at Mandiri Sharia Bank. These findings indicated that the customers of the Mandiri Sharia Bank stated that they are loyal and willing to repeat their banking transaction due to their obedience to the Islamic teaching. The willingness to do the banking transaction according to what is stipulated by the sharia caused the customers to be loyal and willing to repeat their transaction using the banking services provided by the Mandiri Sharia Bank. The insignificant influence of religious commitment toward the quality of services shows that there are doubts toward the existence of the sharia bank, which is still a new concept in Indonesia. Other factors are due to the lack of knowledge in the community toward the operational of the sharia banks; banking regulations that have not fully accommodated the operational services of the sharia bank; the network of sharia banks offices that is not as wide as the network of other general banks; and lack of human resources that specialized in sharia banking.

\section{REFERENCE}

Abdelghani Echchabi dan Hasanuddeen Abd Aziz. 2012. The Relationship Beetween Religiousity and Customer Adoption of Islamic banking Services in Marocco, Oman. Arabian Journal of Business and Management Review, Vol. 1. No. 9.

Achsien, Iggi H., 2000. Investasi Syariah di Pasar Modal, Gramedia Pustaka Utama, Jakarta

Aisyah, Muniaty, 2007. Pengaruh Labelisasi Halal terhadap Keputusan Pembelin Produk Mie Instan Indofood. Etikonomi, Vol. 6, No. 2.

Astogini, D., Wahyudin, W., \& Wulandari, S. Z. 2014. Aspek Religiusitas Dalam Keputusan Transaksi Produk Halal (Studi tentang labelisasi halal pada produk makanan dan minuman kemasan). Jurnal Ekonomi Bisnis dan Akuntansi (JEBA), 13(1).

Astuti, Sri Wahyuni. 2001. Dampak Pemasaran Jasa Rumah Sakit Terhadap Nilai, Kepuasan dan Loyalitas Pasien. Penelitian Pada Pasien Rawat Inap Rumah Sakit Umum di Tiga Ibu Kota Propinsi di Pulau Jawa. Disertasi. Program Studi Ilmu Ekonomi.Pascasarjana Universitas Airlangga. Surabaya.

Aydin, S. \& Özer, G. 2005. How switching costs affect subscriber loyalty in the Turkish mobile phone market: An exploratory study. Journal of Targeting, 14 (2) 
Baesens, B., Viaene, S., Van den Poel, D., Vanthienen, J., \& Dedene, G. (2002). Bayesian neural network learning for repeat purchase modelling in direct marketing. European Journal of Operational Research, 138(1).

Bank Indonesia, 2000. Ringkasan Pokok-pokok Hasil Penelitian; Potensi, Preferensi, dan Perilaku Masyarakat Terhadap Bank Syariah di Pulau Jawa.: Direktorat Penelitian dan Pengaturan Perbankan, Jakarta..

Baloglu, Seymus. 2002. Dimensions of Customer Royalty. Separating Friends From Well Wishers. Cornell Hotel and Restaurant Administration Quartely. Comel University.

Bei, Lien-T. and Chiao, Yu-Ching. 2001. An integrated model for the effects of perceived product, perceived service quality, and perceived price fairness on consumer satisfaction and loyalty. Journal of Consumer Satisfaction, Dissatisfaction and Complaining Behavior. Vol. 14.

Blackwell, R. D., Miniard, P. W., \& Engel, J. F. 2001. Consumer behavior 9th. South-Western Thomas Learning. Mason, $\mathrm{OH}$.

Bloemer, Josee., Ko de Ruyter and Pascal Peeters. 1998. Investigating drivers of bank loyalty: the complex relationship between image, service quality and satisfaction. The International Journal of Bank Marketing. Vol. 16.

Bolton, R. N., Lemon, K. N., \& Verhoef, P. C. 2008. Expanding business-tobusiness customer relationships: Modeling the customer's upgrade decision. Journal of Marketing, 72(1).

Boulding, W., Staelin Kalra, and Zeithaml. V., A. 1993. A Dynamic Process Model of Service Quality: From Expectations to Behavior Intentions. Journal of Marketing Research. Vol. 30 (February).

Caruana, Albert. 2002. Service Loyalty. The Effect of Service Quality and The Mediating Role of Customer Satisfaction. European Journal of Marketing.

Cronin, J. Joseph Jr. and Taylor, Stevent A. 1992. Measuring Service Quality: A Reexanination and Extention. Journal of Marketing. 46 .July.

Cronin, J. J., Brady, M. K., \& Hult, G. T. M. 2000. Assessing the effects of quality, value, and customer satisfaction on consumer behavioral intentions in service environments. Journal of retailing, 76(2).

Chiu, C. M., Hsu, M. H., Lai, H., \& Chang, C. M. (2012). Re-examining the influence of trust on online repeat purchase intention: The moderating role of habit and its antecedents. Decision Support Systems, 53(4).

Chiu, C. M., Wang, E. T., Fang, Y. H., \& Huang, H. Y. (2014). Understanding customers' repeat purchase intentions in $B 2 C$ e-commerce: the roles of utilitarian value, hedonic value and perceived risk. Information Systems Journal, 24(1). 
The Influence of Service Quality, Religious Commitment and Trust on The Customers' Satisfaction and Loyalty and Decision to Do The Transaction in Mandiri Sharia Bank of Jawatimur

Chumpitaz, Ruben dan Paparoidamis , Nicholas . 2007. Service quality, relationship satisfaction, trust, commitment and business-to-business loyalty. European Journal of Marketing. 41 no. 7.

Endang Sulistya Rini, 2007. Pengaruh Economic Content, Resource Content, dan Social Content terhadap Kepercayaan, Kepuasan dan Komitmen serta Relationship Intention Debitur Bank Sumut di Sumatera Utara. Disertasi, Program Pascasarjana Universitas Airlangga. Surabaya..

Dewi Sartika, Ali Mubarok, Indari Laasati. 2011. Hubungan antara Religius Commitment dengan keputusan menggunakan jasa Bank Syariah pada Dosen Unisba. Jurnal Ilmu Sosial, Ekonomi dan Humaniora. Vol. 6 No. 2.

El Junusi, Rahman. 2009. Pengaruh atribut produk islam, komitmen agama, kualitas jasa dan kepercayaan terhadap kepuasan dan loyalitas nasabah bank syari'ah (pada bankmuamalat kota semarang). Annual Conference. The 9th Annual Conference on Islamic Studies (ACIS)

Ferdinand, Augusty. 2000. Struktural Equation Modeling (SEM) Dalam Penelitian Manajemen. Universitas Diponegoro, Semarang:

Fomell C, MD Johnson, EW. Anderson, Jaesung Cha and B. Everin Bryant. 1996. The American Customer Satisfaction Index: Nature, Purpose and Findings. Journal of Marketing. 60. Oktober.

Gatot Yulianto, Purwanto Waluyo, 2004. Pengaruh Keefektifan Komunikasi, Kualitas Teknikal, Kualitas Fungsional dan Kepercayaan Pada Komitmen Keterhubungan Bandara Ahmad Yani Semarang, Telaah Manajemen, Magister Manajemen STIE Stikubank Semarang, Vol.1 Edisi 3.

Griffin , Jill. 2005. Customer Loyalty, Menumbuhkan dan Mempertahankan Kesetiaan Nasabah. Penerbit : Erlangga, Jakarta

Hawkins, D. I., David L. Mothersbaug, dan Roger J. Best. 2007. Consumer Behavior : Building Marketing Strategy. McGraw-Hill. New York.

Holm, Mats G. 2000. Service Quality and Product Quality in Housing Refurbishment. The International Journal of Quality \& Reliability Management. Vol. 17.

Junisi, R. E. 2009. Pengaruh Atribut Produk Islam, Komitmen Agama, Kualitas Jasa and Kepercayaan Terhadap Kepuasan and Loyalitas Nasabah Bank Syari'ah (Pada Bank Muamalat Kota Semarang). In The 9th Annual Conference on Islamic Studies (ACIS). 
Janet Wagner and Gabrielle Rydstrom 2001. Satisfaction, Trust and Commitment in Consumers = Relationships With Online Retailers", in E - European Advances in Consumer Research Volume 5, eds. Andrea Groeppel-Klien and Frank-Rudolf Esch, Provo, UT : Association for Consumer Research.

Kadir, Abd. Rahman. 2001. Pengaruh Komitmen Manajemen Bank Terhadap Tingkat Kepuasan Kerja Karyawan dan Tingkat Kepuasan Nasabah di Sulawesi Selatan. Disertasi Universitas Airlangga Surabaya.

Bonne, K., Vermeir, I., Bergeaud-Blackler, F., \& Verbeke, W. 2007. Determinants of halal meat consumption in France. British Food Journal, 109(5).

Kotler \& Armstrong. 2009. Marketing (9th ed). Pearson International Edition.

Kuntjara, K. 2007. Analisis Faktor-faktor yang mempengaruhi Minat Beli Ulang Nasabah (Studi kasus di PT Wijaya Karya Beton Wilayah IV; Jateng, DIY, Kalsel dan Kalteng). Doctoral dissertation, Universitas Diponegoro, Semarang.

Lassar, Walfried M., Chris Manolis \& Winsor, Robert D.. 2000. Service Quality Perspectives and Satisfaction in Private Banking. The International Journal of Bank Marketing. Vol. 18.

Louro, M. J., Pieters, R., \& Zeelenberg, M. 2005. Negative Returns on Positive Emotions: The Influence of Pride and Self-Regulatory Goals on Repurchase Decisions. Journal of Consumer Research, 31(4).

Macdonald, E. K., \& Sharp, B. M. 2000. Brand Awareness Effects on Consumer Decision Making for a Common, Repeat Purchase Product:: A Replication. Journal of business research, 48(1).

Mowen, John C dan Michael Minor. 2002. Perilaku Nasabah. Jilid Satu Edisi Kelima. Alih Bahasa Lina

Salim. Jakarta: Erlangga. Natalisa, Diah. 2000. Pengaruh Komitmen Manajemen Terhadap Kualitas Layanan Untuk Meningkatkan Kepuasan Nasabah Maskapai Penerbangan Domistik Sudut Pandang Nasabah dan Penyaji Jasa. Disertasi. Program Studi Ilmu Ekonomi.Pascasarjana Universitas Airlangga. Surabaya.

Nazir, Mohammad. 1988. Metode Penelitian. Cetakan Ketiga. Jakarta: Ghalia Indonesia.

Oliver R. L. 1981. Measurement and Evaluation of Satisfaction Process in Retail Setting. Journal of Retailing. 57.

Olorunniwo, F., Hsu, M. K., \& Udo, G. J. 2006. Service quality, customer satisfaction, and behavioral intentions in the service factory. Journal of Services Marketing, 20(1). 
The Influence of Service Quality, Religious Commitment and Trust on The Customers' Satisfaction and Loyalty and Decision to Do The Transaction in Mandiri Sharia Bank of Jawatimur

Parasuraman, V., A. Zeithaml and L. L. Beny. 1985. A Conceptual Model of Service Quality and its Implication for Future Research. Journal of Marketing Research. 49.

Parasuraman, V., A. Zeithaml and L. L. Beny. 1996. The Behavioral Consequences of Service Quality. Journal of Marketing. 40.

Pavlou, P. A., \& Gefen, D. 2004. Building effective online marketplaces with institution-based trust. Information Systems Research, 15(1).

Peppers, Don dan Rogers, Martha. 2004. Managing Customer Relationships: A Strategic Framework. USA: John Wiley and Sons, Inc.

Preis, M. W. 2003. The impact of interpersonal satisfaction on repurchase decisions. Journal of supply chain management, 39(2).

Rahma, E. S. 2007. Analisis Pengaruh Kualitas Layanan dan Citra Merek terhadap Minat Beli dan Dampaknya pada Keputusan Transaksi (Studi pada Pengguna Telepon Seluler Merek Sony Ericson di Kota Semarang) (Doctoral dissertation, Universitas Diponegoro).

Rakhman, A., Farida, N., \& Listyorini, S. 2014. Pengaruh Kualitas Layanan dan Kepercayaan terhadap Loyalitas Nasabah dengan Kepuasan Nasabah sebagai Variabel Intervening Studi Pada Nasabah CV. AHASS Brahma Motor. Jurnal Ilmu Administrasi Bisnis, 3(4).

Jiang, P., \& Rosenbloom, B. (2005). Customer intention to return online: price perception, attribute-level performance, and satisfaction unfolding over time. European Journal of Marketing, 39(1/2).

Said, Sudirman. 2004. Pengaruh Kemampuan Mengolah Informasi Terhadap Loyalitas Nasabah Bank Rakyat Indonesia (BRI) di Sulawesi Tenggara. Disertasi Universitas Airlangga Surabaya.

Setiawan, Mulyo Budi \& Ukudi. 2007. Pengaruh Kualitas Layanan, Kepercayaan dan Komitmen terhadap Loyalitas Nasabah. Jurnal Bisnis dan Ekonomi. (Vol 14 No.2)

Sharma, N., \& Patterson, P. G. 2000. Switching costs, alternative attractiveness and experience as moderators of relationship commitment in professional, consumer services. International journal of service industry management, 11(5).

Siburian, Ind Tigana Prasetyo, Handoyo Djoko W dan Widayanto 2010. Pengaruh Kualitas Layanan dan Kepuasan Nasabah terhadap Loyalitas Nasabah pada Bank Mandiri Semarang. Jurnal Ilmu Administrasi Bisnis 
Singh, H. 2006. The importance of customer satisfaction in relation to customer loyalty and retention. Academy of Marketing Science, 60 .

Suhardi, Gunarto. 2006. Faktor-Faktor yang Mempengaruhi Kepercayaan dan Loyalitas Nasabah Perbankan Di Surabaya. Jurnal KINERJA. Vol. 10 No.1

Taylor, S. A., \& Hunter, G. 2003. An exploratory investigation into the antecedents of satisfaction, brand attitude, and loyalty within the (B2B) $e C R M$ industry. Journal of Consumer Satisfaction Dissatisfaction and Complaining Behavior, 16.

Thejasukmana, V. A. (2014). Analisis Pengaruh Experiential Marketing Terhadap Transaksi Ulang Nasabah The Vinnette (House of Bovin and Lynnette) Surabaya. Jurnal Strategi Pemasaran, 2(1).

Tjiptono 2004. Pemasaran Jasa. Malang: Bayumedia.

Tjiptono, Fandy \& Gregorius Chandra. 2011. Service, Quality \& Satisfaction Edisi 3. Yogyakarta: ANDI

Wasid Mansyur, 2010. Agama Konstektual dan Kemaslahatan Umat, http://pesma.sunan-ampel.ac.id/?p=18, diunduh tanggal 11 September 2010, jam 21.30.15

Zboja, J. J., \& Voorhees, C. M. 200). The impact of brand trust and satisfaction on retailer repurchase intentions. Journal of Services Marketing, 20(6).

Zeithaml, Valerie A., and Bitner, Mary Jo. 1996. Services Marketing. $1^{\text {st }}$ edition New York: McGrawHill International Editions.

Zikmund, W.G., 2003. Business Research Methods, 7th Edition. South Western, Thomson. 